\title{
The effect of eutrophication abatement on the bivalve Scrobicularia plana
}

\author{
T. Verdelhos*, J.M. Neto, J.C. Marques, M.A. Pardal \\ IMAR - Institute of Marine Research, Department of Zoology, University of Coimbra, 3004-517 Coimbra, Portugal
}

Received 2 August 2004; accepted 23 November 2004

\begin{abstract}
Over the last few decades, the excessive growth of macroalgae and decline of seagrass beds, associated with increased eutrophication, has become a worldwide problem. It is known that submersed aquatic vegetation (SAV) offers stable habitats, allowing the continuous availability of food and protection against predators and contributing to biodiversity, sediment stability and water transparency when compared to areas covered by macroalgae mats. In the Mondego estuary (Portugal), several mitigation measures (nutrient-load reduction, seagrass-bed protection and freshwater-circulation enhancement) were implemented in 1998 in order to promote the recovery of the seagrass beds and the entire surrounding environment following a long period of eutrophication. Here the success of this restoration project is evaluated by comparing the water nutrient concentrations, the extent of seagrass cover and the dynamics of the bivalve Scrobicularia plana before and after the implementation of the management measures. During the period in which environmental quality declined, S. plana's adult abundance, total biomass and growth production also declined, parallel with the almost total disappearance of Zostera noltii. After the implementation of management measures, dissolved nutrients and green macroalgal blooms were much reduced, and seagrass beds started to recover. The $S$. plana population also responded positively, becoming more structured (including individuals of all age classes), with higher biomass and growth production.
\end{abstract}

(C) 2004 Elsevier Ltd. All rights reserved.

Keywords: eutrophication; management; Scrobicularia plana; population dynamics; ecological restoration

\section{Introduction}

Eutrophication, or excessive organic carbon input associated with nutrient enrichment, of coastal waters is now widely recognized as a major worldwide threat (Raffaeli et al., 1998). As a response to global human disturbance, in recent years there has been an enormous increase in restoration as a technique for reversing habitat degradation worldwide (de Jonge et al., 2000). The general purpose of restoration projects is to help

\footnotetext{
* Corresponding author.

E-mail address: tverdelhos@ci.uc.pt (T. Verdelhos).
}

a habitat return from an altered or disturbed condition to a previously existing natural condition (Kennish, 2000). To evaluate the success of restoration plans, one must at least understand the processes which have driven the observed ecological changes. There is a need to monitor the restoration and to assess its success (Kennish, 2000; Pardal et al., 2004).

In the Mondego estuary (Portugal), eutrophication has triggered serious biological changes, which have led to a progressive replacement of seagrasses (Zostera noltii) by opportunistic macroalgae (Marques et al., 1997, 2003; Pardal et al., 2000, 2004; Martins et al., 2001; Cardoso et al., 2002, 2004; Dolbeth et al., 2003). Since the late 1980s, green macroalgal blooms have been 
observed in the southern arm of the Mondego estuary as a major symptom of eutrophication, due to the high availability of nutrients (nitrogen and phosphorus), coupled with high water residence time (Marques et al., 1997, 2003; Pardal et al., 2000, 2004; Martins et al., 2001; Cardoso et al., 2002, 2004; Dolbeth et al., 2003). As a consequence, $Z$. noltii beds, considered the richest habitat in terms of biodiversity and productivity (Edgar, 1990; Marques et al., 1997; Cardoso et al., 2004), suffered a drastic reduction during the last two decades (Marques et al., 1997; Pardal et al., 2000, 2004; Martins et al., 2001). This led to a shift in primary producers, from $Z$. noltii towards faster growing green macroalgae (Raffaeli et al., 1998; Pardal et al., 2000; 2004; Cloern, 2001; Martins et al., 2001). Changes in the trophic structure and, ultimately, in the composition and productivity of entire macrobenthic assemblages have been reported (Dolbeth et al., 2003; Cardoso et al., 2004), leading to less structured and impoverished macrofaunal communities.

The present study evaluates the success of a restoration project implemented in the Mondego estuary, focussing on the dynamics of Scrobicularia plana, a long-lived deposit-feeding bivalve species, living in muddy to sandy sediments (Hughes, 1969, 1970a,b; Guelorget and Mazoyer-Mayére, 1983; Essink et al., 1991; Sola, 1997; Guerreiro, 1998). Long-term data sets (8 years) are required in order to capture slow ecological processes (e.g. population dynamics of long-lived organisms), rare events (e.g. floods) and complex phenomena, in which a long span of time is required to detect changes or trends (Franklin, 1989).

\section{Materials and methods}

\subsection{Study site}

The Mondego estuary, located on the Atlantic coast of Portugal $\left(40^{\circ} 08^{\prime} \mathrm{N}, 8^{\circ} 50^{\prime} \mathrm{W}\right)$ comprises a northern and a southern arm, separated by the alluvial Murraceira Island (Fig. 1). The northern arm is deeper (4-8 m during high tide, tidal range about 1-3 m) and constitutes the main navigation channel and the location of the Figueira da Foz harbour. The southern arm is shallower (2-4 $\mathrm{m}$ during high tide, tidal range 1-3 $\mathrm{m}$ ) and is almost silted up in the upper zones, constituting a kind of coastal lagoon in which the water circulation is mostly dependant on the tides and on the freshwater input from the Pranto River, a small tributary (Marques et al., 1997; Lillebø et al., 1999; Pardal et al., 2000, 2004). The discharge from this tributary is controlled by a sluice (Pardal et al., 2000, 2004; Cardoso et al., 2004) and is regulated according to the irrigation needs in rice fields in the Mondego Valley (Martins et al., 2001).

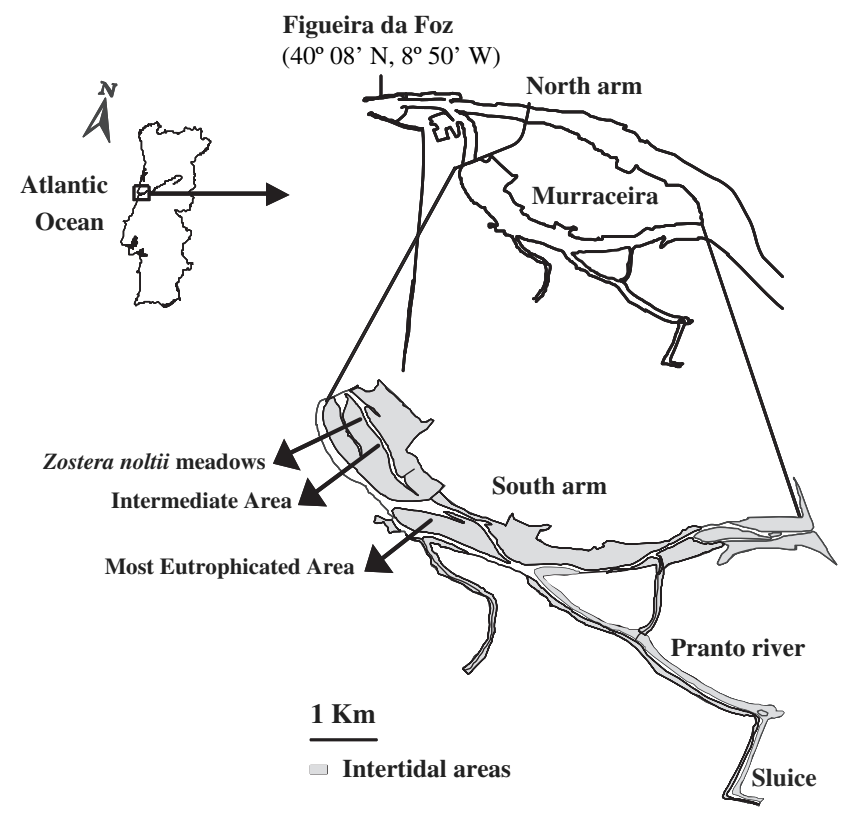

Fig. 1. Location of the sampling areas on the Mondego estuary $\left(40^{\circ}\right.$ $\left.08^{\prime} \mathrm{N}, 8^{\circ} 50^{\prime} \mathrm{W}\right)$.

Since the 1980s, Zostera noltii beds have been drastically reduced in area extent and biomass in the southern arm (Cardoso et al., 2004; Pardal et al., 2004). For instance, an area of 15 ha was progressively reduced to 1.6 ha in 1993 and to less than $300 \mathrm{~m}^{2}$ in 1997. In 1998, several mitigation measures were applied. The hydraulic regime in the southern arm was improved by enlarging the connection between the two arms. The Pranto sluiceopening regime was minimized in such a way that most of the nutrient enriched freshwater from the Pranto River is diverted to the northern arm (by another sluice located more upstream), reducing the nutrient loading in the southern arm. In addition, the remaining seagrass patches were protected with wooden stakes to prevent further disturbance of that area (by fishermen digging in the sediment and looking for bait), and several forums were run to inform local people of the ecological and economic importance of the seagrass beds.

Three study areas were established in the southern arm (Fig. 1):

(a) Zostera noltii beds, a non-eutrophic area located downstream, characterized by muddy sediments with high organic matter content $(6.3 \pm 1.5 \%)$, higher salinity values (20-30), lower total inorganic nitrogen concentrations $\left(15-30 \mu \mathrm{mol} \mathrm{N}{ }^{-1}\right)$, and higher water-flow velocity $\left(1.2-1.4 \mathrm{~m} \mathrm{~s}^{-1}\right)$;

(b) an intermediate eutrophic area, located just upstream of the previous study area, has no seagrass cover, although some rhizomes remain in the sediment. The physical-chemical conditions are otherwise similar to those of the $Z$. noltii beds but with lower sediment organic matter content $(5.8 \pm 1.3 \%)$; 
(c) the most eutrophic area, in the inner part of the estuary, characterized by the absence of rooted macrophytes (for more than 15 years) and now covered seasonally by green macroalgae (Pardal et al., 2000, 2004; Martins et al., 2001; Cardoso et al., 2002, 2004). This sand flat presents lower organic matter content $(3.7 \pm 1.0 \%)$, lower salinities (15-25), higher total inorganic nitrogen concentrations $(30-50 \mu \mathrm{mol}$ $\left.\mathrm{N}^{-1}\right)$, and lower water flows $\left(0.8-1.2 \mathrm{~m} \mathrm{~s}^{-1}\right)$.

\subsection{Methods}

Sampling was carried out from January 1993 to September 1995 and from December 1998 to December 2000 in the three areas. Between October 1995 and January 1997, only the most eutrophic area was sampled. Samples were taken fortnightly during the first 18 months and monthly thereafter. At each study area, 5-10 sediment cores corresponding to a total area of $0.2115-$ $0.4230 \mathrm{~m}$ were taken to a depth of $20 \mathrm{~cm}$. Samples were washed over a $500 \mu \mathrm{m}$ mesh sieve, placed into plastic bottles and preserved in $4 \%$ buffered formalin. On each occasion temperature and salinity were measured in situ in water pools. Water samples were collected for analysis of dissolved inorganic nitrogen and dissolved inorganic phosphorus. Later, in the laboratory, animals were separated and kept in $70 \%$ ethanol. Scrobicularia plana individuals were counted and its total length measured. Length-weight relationships were determined for production estimates. Preliminary ANOVA of length $\times$ ashfree dry weight (AFDW) relationships indicated no significant seasonal differences. Therefore, an overall regression equation was used $(\mathrm{AFDW}=0.00000991 \times$ total length $\left.2.68809, r^{2}=0.97, N=152\right)$. Biomass was calculated as AFDW (weight loss after $8 \mathrm{~h}$ of incineration at $450{ }^{\circ} \mathrm{C}$ of specimens previously dried at $60{ }^{\circ} \mathrm{C}$ for $72 \mathrm{~h}$ ). Plant biomass (Chlorophycea, Rhodophycea, Zostera noltii leaves and rhizomes) and organic matter content of the sediment was determined as AFDW after oven drying at $60{ }^{\circ} \mathrm{C}$ for $72 \mathrm{~h}$ and combustion at $450{ }^{\circ} \mathrm{C}$ for $8 \mathrm{~h}$.

\subsection{Growth and production}

Growth rates were estimated by tracking cohorts in size frequency distributions over successive sampling dates using the ANAMOD software package (Nogueira, 1992). Since the growth rates exhibited seasonal changes, we adjusted empirical data to an adequate mathematical model (Gaschütz et al., 1980), based on the Von Bertalanffy equation, expressed as:

$L_{t}=L_{\infty}\left(1-e^{-\left[k D\left(t-t_{0}\right)+C\left(\frac{k D}{2 \pi}\right) \sin 2 \pi\left(t-t_{s}\right)\right]}\right) \frac{1}{D}$

where $L_{t}$ is the length of the organism at a given moment $t$; $L_{\infty}$ is the maximum possible length of the organism; $t_{0}$ is the instant when the organism would have a length $=0 ; t_{\mathrm{s}}$ is the time interval between start of growth and the first oscillation, with growth being expressed by a sine curve with a period of 1 year; $k$ is the intrinsic growth rate; $C$ is a constant between 0 and 1 , inherent to the species and $D$ is a parameter expressing metabolic deviations from the von Bertalanffy rule.

Annual production was estimated upon cohort recognition, determining growth increments or net production $(P)$ as described in Dauvin (1986).

\section{Results}

\subsection{Nutrients and plant biomass}

Dissolved inorganic nitrogen concentrations were significantly different before and after the introduction of mitigation measures (Zostera noltii beds, Wilcoxon two-sample test, $W=3689, P<0.05$; most eutrophic area, Wilcoxon two-sample test, $W=3174.5, P<0.05$ ), being markedly reduced in the post-mitigation period for both areas (Fig. 2). The same pattern was also observed for N/P ratios. Significant differences were detected between pre and post-mitigation periods for both sites $(Z$. noltii beds, Wilcoxon two-sample test,
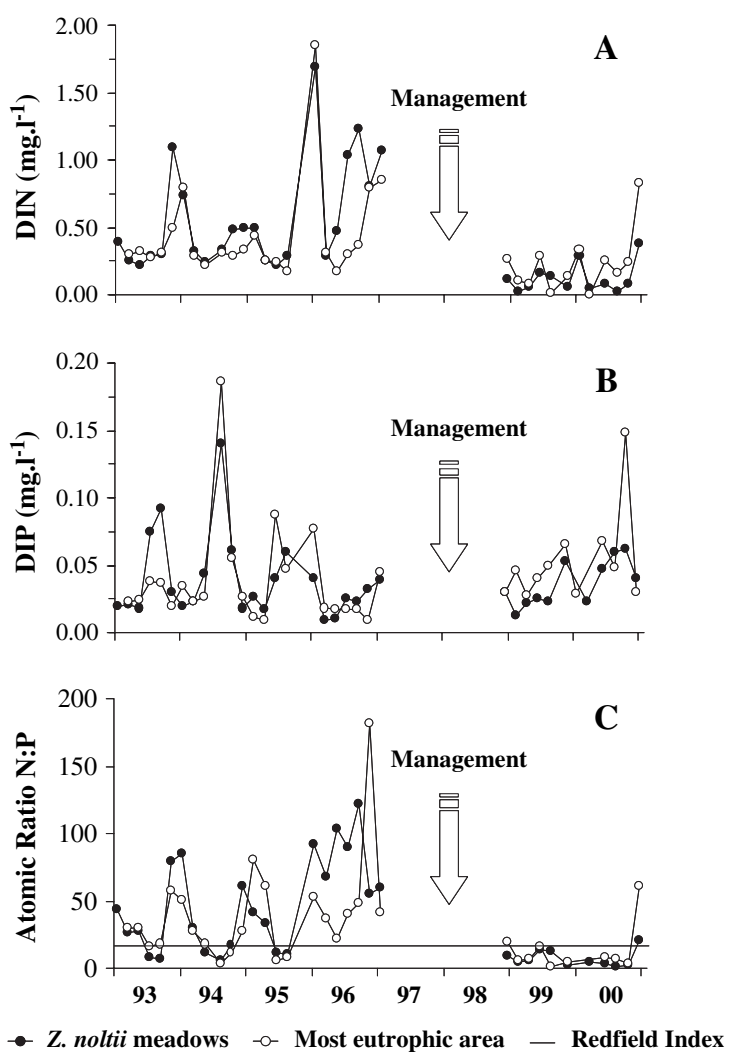

Fig. 2. Long-term variation in estuarine nutrient concentrations. (A) Dissolved inorganic nitrogen (DIN); (B) dissolved inorganic phosphorus (DIP); (C) N/P atomic ratio (Redfield ratio). 
$W=526, P<0.05$; most eutrophic area, Wilcoxon twosample test, $W=445, P<0.05$ ).

Regarding seagrass biomass, significantly different developments were observed in the pre- and post-mitigation periods (Wilcoxon two-sample test, $W=1822$, $P<0.05$ ). From 1993 to 1997 , the total biomass of Zostera noltii, declined sharply and in early 1998 the lowest biomass ( $5 \mathrm{~g} \mathrm{AFDW} \mathrm{m}^{-2}$ ) was recorded. After the introduction of mitigation measures, in 1998, seagrass beds gradually recovered (Fig. 3A). Moreover, in the intermediate area (Wilcoxon two-sample test, $W=1049$, $P<0.05$ ) and in the most eutrophic area (Wilcoxon twosample test, $W=933, P<0.05)$, there were also significant differences between both periods. In 1993 and 1995, macroalgal blooms were common, but they were never present after post-mitigation measures (Fig. 3B,C).

\subsection{Scrobicularia plana abundance and biomass}

Scrobicularia plana abundance and biomass increased markedly during the study period in the three areas (Zostera noltii beds, Wilcoxon two-sample test, $W=468$, $P<0.05$; intermediate area, Wilcoxon two-sample test, $W=650.5, P<0.05$; eutrophic area, Wilcoxon twosample test, $W=1119, P<0.05)$. In the $Z$. noltii meadows (Fig. 4A) and in the intermediate area (Fig. 4B) from 1993 to 1995 , S. plana abundance was relatively
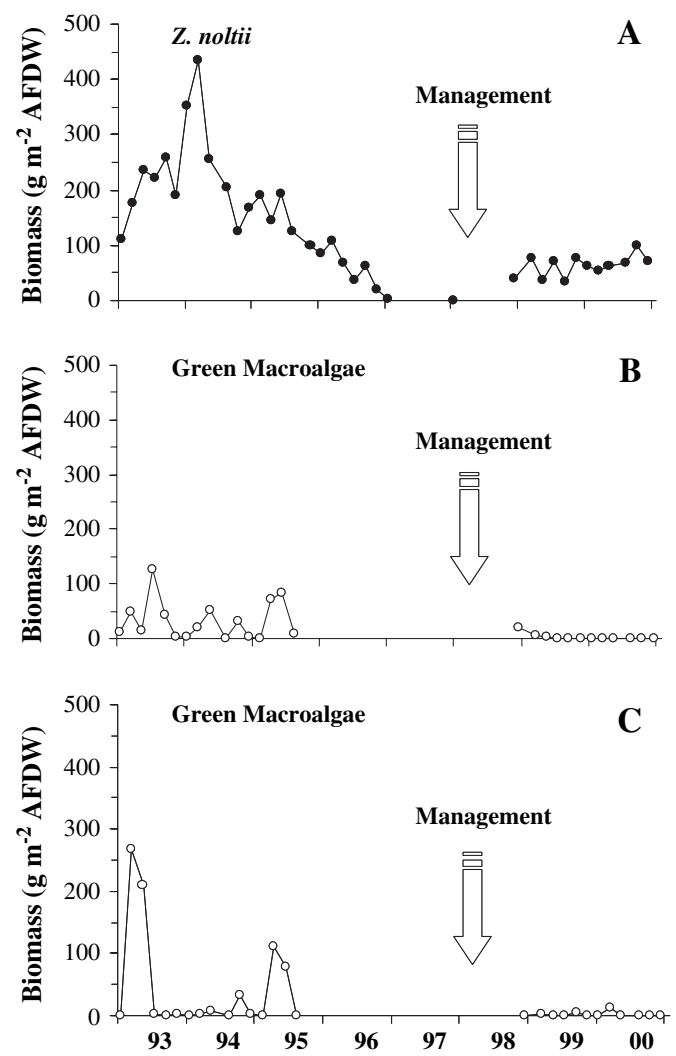

Fig. 3. Long-term variation of plant biomass. (A) Zostera noltii meadows; (B) intermediate eutrophic area; (C) most eutrophic area.
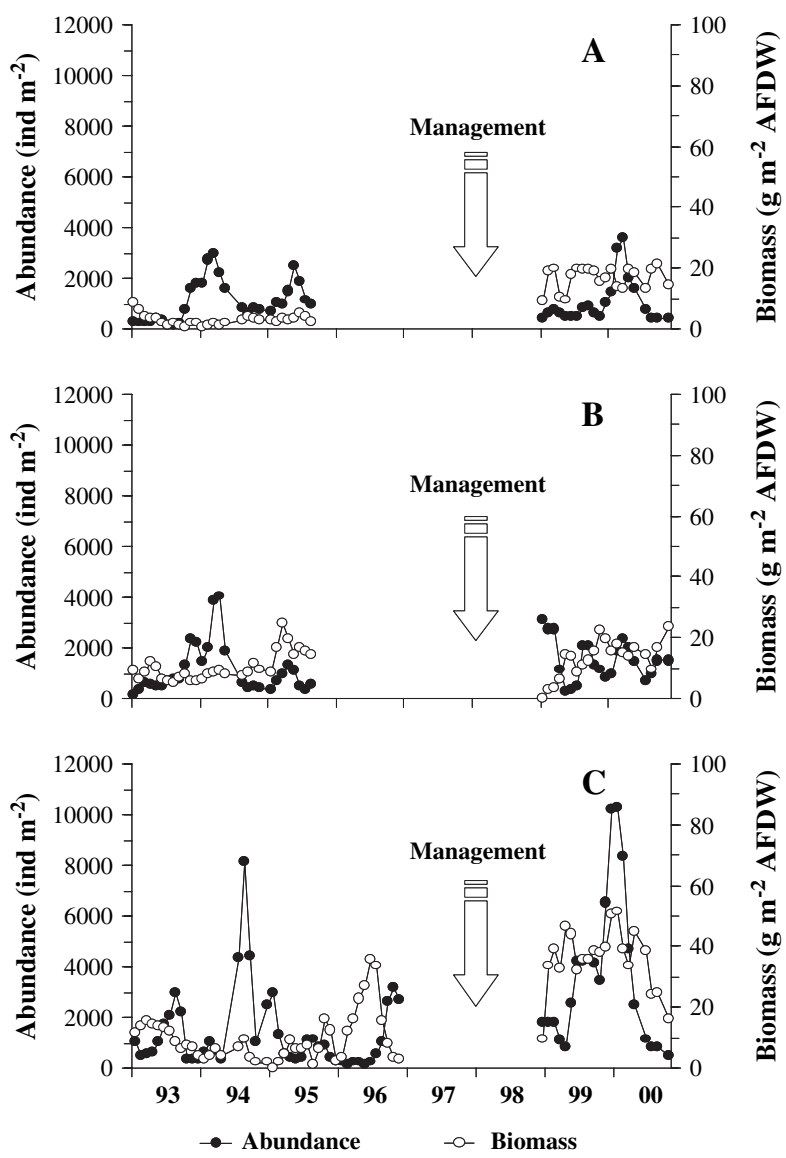

Fig. 4. Long-term variation of Scrobicularia plana total abundance and biomass. (A) Zostera noltii meadows; (B) intermediate eutrophic area; (C) most eutrophic area.

low with recruitment occurring in winter and early spring. At the eutrophic area (Fig. 4C) in the same period, density was consistently higher with abundance increments occurring from mid-spring to end of summer. Nevertheless, in the post-mitigation period, increments occurred also from winter and early spring, just like the two previous areas. The density of larger individuals $(>10 \mathrm{~mm})$ also increased significantly after management (Fig. 5) in the three areas ( $Z$. noltii beds, Wilcoxon two-sample test, $W=1296.5, P<0.05$; intermediate area, Wilcoxon two-sample test, $W=1627$,

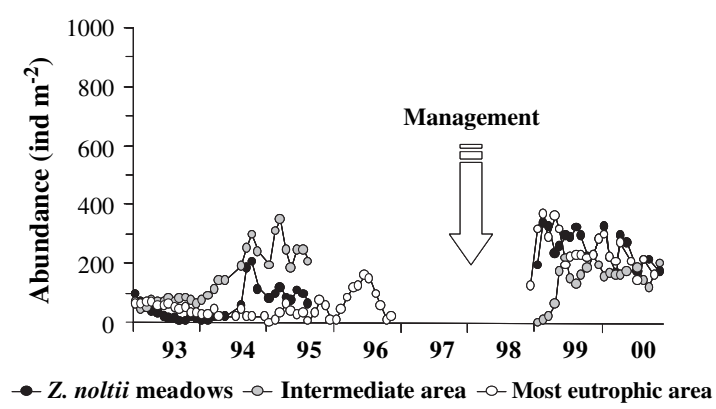

Fig. 5. Abundance of Scrobicularia plana individuals $>10 \mathrm{~mm}$. 
$P<0.05$; eutrophic area, Wilcoxon two-sample test, $W=2072, P<0.05)$ demonstrating a more structured population (Fig. 6).

\subsection{Population structure and growth}

It was possible to recognise initially five cohorts, with the recruitment of a spring cohort once a year (Fig. 7A). The population became more structured in the postmitigation period, including individuals of almost all size classes, in contrast with the population between 1993 and 1995, which was mainly composed of younger individuals $(<10 \mathrm{~mm})$. Field growth data from cohorts C6, C7 and C8 were used to calibrate a mathematical model proposed by Gaschütz et al. (1980) (Fig. 7B). Growth rates were clearly higher from spring to early fall, decreasing during the colder months. Based on the field growth rates and on the recruitment period, the life span of the species was estimated to be $62 \pm 1$ months.
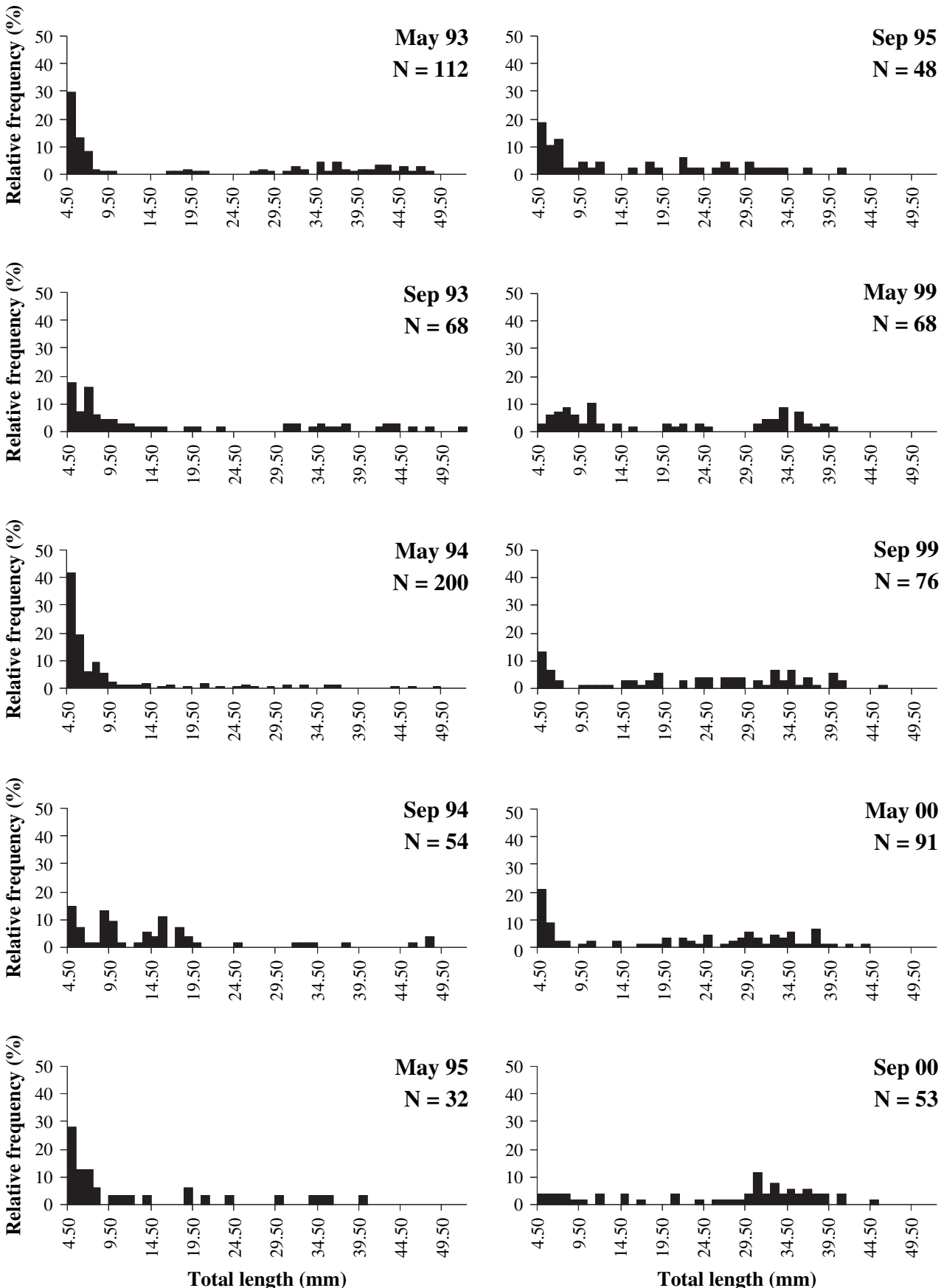

Fig. 6. Size frequency distribution of the Scrobicularia plana population. 
A
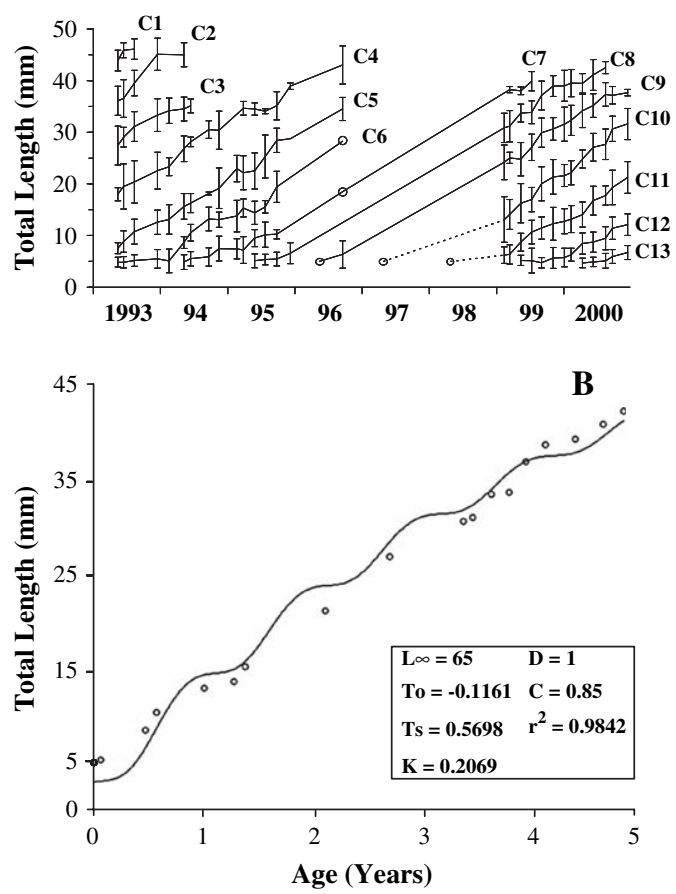

Fig. 7. Scrobicularia plana field growth rates (average growth \pm standard deviation) (A) and mathematical growth model for S. plana cohorts (B).

\subsection{Production}

The annual production estimates showed that, after management measures were implemented, growth productivity $(P)$ was two to three times higher in 1999 and 2000 than in 1993 and 1994. On the contrary, $P / \bar{B}$ ratios were lower in 1999 and 2000 (Table 1) due to a five- to ten-fold increase of the mean population biomass $(\bar{B})$.

\section{Discussion}

\subsection{Nutrients, macrophyte and macroalgae biomass}

As a whole, the nutrient-enriched waters, coupled with high residence time and low transparency led to a gradual decline of the Zostera noltii community throughout the study period (almost disappearing in 1998), outcompeted by macroalgae as a consequence of the eutrophication process. Such a change in primary producers can led to structural changes in the ecosystem causing an impoverishment of the associated macrofaunal benthic communities (Cardoso et al., 2004; Pardal et al., 2000, 2004).

From 1993 to 1997, green macroalgae biomass suffered several oscillations (Martins et al., 2001), depending upon temperature, salinity and hydrodynamic conditions, with huge spring blooms followed by sudden algal crashes, which caused instability in the community (Cardoso et al., 2004; Pardal et al., 2004). Since the introduction of management measures in 1998 however, green macroalgal biomass decreased and no spring blooms were observed, certainly due to a reduction in nutrient loading, to an increase in fresh water circulation and generally to an increase in stabilisation of the abiotic conditions. In parallel, the management measures implemented also showed satisfactory results with the Zostera noltii meadow progressively recovering during the subsequent years, increasing their biomass and enlarging their area.

Table 1

Scrobicularia plana annual growth production estimations in different European populations along a latitudinal gradient

\begin{tabular}{lllll}
\hline & $\begin{array}{l}P \\
\left(\mathrm{~g} \mathrm{~m}^{-2} \mathrm{year}^{-1}\right)\end{array}$ & $\begin{array}{l}\bar{B} \\
\left(\mathrm{~g} \mathrm{~m}^{-2}\right)\end{array}$ & $P / \bar{B}$ & References \\
\hline Conway Bay, Wales & 2.97 & 4.37 & 0.68 & Hughes (1970a,b) \\
Conway Bay, Wales & 13.41 & 46.24 & 0.29 & Hughes (1970a,b) \\
Lynher estuary, England & 0.48 & 2.18 & 0.22 & Green (1957) \\
Gironde estuary, France & 0.62 & 0.11 & 5.69 & Essink et al. (1991) \\
Gironde estuary, France & 0.26 & 1.63 & 0.16 & Essink et al. (1991) \\
Arcachon Bay, France & 6.38 & 9.67 & 0.66 & Bachelet (1982) \\
Bidasoa estuary (1987), Spain & 105.9 & 84.05 & 1.26 & Sola (1997) \\
Bidasoa estuary (1988), Spain & 49.55 & 58.99 & 0.84 & Sola (1997) \\
Bidasoa estuary (1989), Spain & 96.21 & 65.01 & 1.48 & Sola (1997) \\
Prévost lagoon (Mediterranean), France & 424.80 & 115.43 & 3.68 & Guelorget and Mazoyer-Mayére (1983) \\
Prévost lagoon (Mediterranean), France & 32.21 & 5.69 & 5.4 & Guelorget and Mazoyer-Mayére (1983) \\
Prévost lagoon (Mediterranean), France & 27.36 & 9.03 & 3.03 & Guelorget and Mazoyer-Mayére (1983) \\
Mondego estuary (1993), Portugal & 4.08 & 5.68 & 0.72 & Present study \\
Mondego estuary (1994), Portugal & 3.11 & 2.67 & 1.16 & Present study \\
Mondego estuary (1999), Portugal & 14.13 & 20.96 & 0.67 & Present study \\
Mondego estuary (2000), Portugal & 9.34 & 18.61 & 0.5 & Present study \\
Tagus estuary, Portugal & 24.71 & - & - & Guerreiro (1998) \\
Mira estuary, Portugal & $1.67-7.34$ & - & - & Guerreiro (1998) \\
\hline
\end{tabular}




\subsection{Scrobicularia plana abundance and biomass}

During the whole study period, Scrobicularia plana showed a clear spatial pattern along the eutrophication gradient, with higher abundance values in the most eutrophic area. This elevated density derived from higher juvenile recruitment during spring and early summer, consistent with other southern European populations (Guelorget and Mazoyer-Mayére, 1983; Sola, 1997; Guerreiro, 1998). Although recruitment was higher, the most eutrophic area exhibited less adult individuals, probably related to a spatial dispersion towards the other two areas. Despite the restricted mobility of this species, there are several references to dispersion of S. plana (Hughes, 1969, 1970a,b; Guelorget and Mazoyer-Mayére, 1983; Sola, 1997; Guerreiro, 1998) and among other bivalve species (Norkko et al., 2001) over short and medium distances.

Juvenile recruitment seems to have been negatively influenced by the presence of green macroalgae, as it was more important in 1994, when macroalgae was absent, than in 1993 or 1995 when spring blooms were common. Moreover, since 1999, abundance increased and recruitment was even more pronounced, showing the importance of the management protection measures.

Adults (i.e. $>10 \mathrm{~mm}$ ) were also shown to be sensitive to eutrophication impacts, particularly with respect to macroalgal oscillations (consecutive blooms and crashes), and like juveniles, responded positively to the management measures. The abundance of adults increased greatly after 1999, and consequently, became more important for the population structure, leading to an important increase in Scrobicularia plana biomass.

\subsection{Population structure, growth and life span}

As in other European populations, during the whole study period Scrobicularia plana recruitment occurred over a period of several months, i.e. from early spring to summer. Nevertheless, only a single new cohort could be distinguished each year. Moreover, like other bivalve species (Beukema et al., 2001), recruitment was more intensive after a severe winter (e.g. 1994), and subsequent years were often characterised by lesser recruitments. Consequently, the population structure is usually dominated by the cohorts derived from the more abundant recruitment. Following each recruitment, a sudden reduction in abundance occurred due to high mortality rates, revealing a strong post-reproduction mortality, as stated in several previous studies (Hughes, 1970a,b; Guelorget and Mazoyer-Mayére, 1983; Sola, 1997; Guerreiro, 1998). In the present study, the direct effect of the management measures could be seen as a decrease in $S$. plana mortality with a consequent increase in the proportion of adult individuals originating a more structured population and an increase in the population biomass.
Each cohort exhibited an approximately 5-year life span, as recorded in other southern European populations (Bachelet, 1982; Guelorget and Mazoyer-Mayére, 1983; Sola, 1997; Guerreiro, 1998), although the species appears to exist along a latitudinal gradient, with longer life spans, slower growth rates, and lower production values in northern populations (Table 1). Field growth rates were also similar to other reported southern European populations (Bachelet, 1982; Guelorget and Mazoyer-Mayére, 1983; Sola, 1997; Guerreiro, 1998), conditioned by individual size and annual season. In fact, growth rates were higher during spring and summer and during the first years of life.

\subsection{Production}

Scrobicularia plana growth production $(P)$ and mean population biomass $(\bar{B})$ appeared to be negatively influenced by macroalgal blooms and its sudden crashes. Both $P$ and $\bar{B}$ were much lower in 1993 and 1994. Moreover in 1999 and $2000 P / \bar{B}$ decreased, showing a positive influence of the implemented measures on reducing eutrophication effects and revealing the greater importance of mean population biomass.

Comparing several Scrobicularia plana populations, it was possible to establish a latitudinal gradient along the Atlantic seaboard (Table 1). Despite few exceptions derived from local climate conditions and from different methodologies used in estimations, populations from lower latitudes are characterised by shorter life span, higher growth rates, and higher annual production (Green, 1957; Hughes, 1969, 1970a,b; Guelorget and Mazoyer-Mayére, 1983; Essink et al., 1991; Sola, 1997; Guerreiro, 1998).

\section{Conclusions}

As a general conclusion, the Scrobicularia plana population was negatively affected by the eutrophication process, in terms of abundance, biomass, juvenile recruitment, population structure, and annual production. The species responded positively to the management measures implemented in 1998 to protect and recover Zostera noltii beds, which led to a more structured and stable population, with higher abundance and biomass, which was reflected in annual production increases.

\section{References}

Bachelet, G., 1982. Quelques problemes liés à l'estimation de la production secondaire. Cas des bivalves Macoma balthica et Scrobicularia plana. Oceanológica Acta 4, 421-431. 
Beukema, J.J., Dekker, R., Essink, K., Michaelis, H., 2001. Synchronized reproductive success of the main bivalve species in the Wadden Sea: causes and consequences. Marine Ecology Progress Series 211, 143-155.

Cardoso, P.G., Lillebø, A.I., Pardal, M.A., Ferreira, S.M., Marques, J.C., 2002. The effect of different primary producers on Hydrobia ulvae population dynamics: a case study in a temperate intertidal estuary. Journal of Experimental Marine Biology and Ecology 277, 173-195.

Cardoso, P.G., Pardal, M.A., Lillebø, A.I., Ferreira, S.M., Marques, J.C., Raffaelli, D., 2004. Dynamic changes of seagrass assemblages under eutrophication and implications for recovery. Journal of Experimental Marine Biology and Ecology 302 (2), 233-248.

Cloern, J.E., 2001. Our evolving conceptual model of the coastal eutrophication problem. Marine Ecology Progress Series 210, 223-253.

Dauvin, J.C., 1986. Biologie, dynamique et production d'une population d' Abra alba (Wood) (Mollusque-bivalve) de la baie de Morlaix (Manche occidentale). Journal of Experimental Marine Biology and Ecology 97, 151-180.

Dolbeth, M., Pardal, M.A., Lillebø, A.I., Azeiteiro, U., Marques, J.C., 2003. Short and long-term effects of eutrophication on the secondary production of an intertidal macrobenthic community. Marine Biology 143, 1229-1238.

Edgar, G.J., 1990. The influence of plant structure on the species richness, biomass and secondary production of macrofaunal assemblages associated with Western Australian seagrass beds. Journal of Experimental Marine Biology and Ecology 144, 205-234.

Essink, K., Beukema, J.J., Coosen, J., Craeymeersch, J.A., Ducrotoy, J.P., Michaelis, H., Robineau, B., 1991. Population dynamics of the bivalve mollusc Scrobicularia plana (da Costa): comparisons in time and space. In: Elliot, M., Ducrotoy, J.P. (Eds.), Estuaries and Coasts: Spatial and Temporal Intercomparisons. Olsen \& Olsen, Fredensborg, Denmark, pp. 167-172.

Franklin, J.F., 1989. Importance and justification of long-term studies in ecology. In: Likens, G.E. (Ed.), Long-Term Studies in Ecology. Approaches and Alternatives. Springer-Verlag, New York, pp. 3-19.

Gaschütz, G., Pauly, D., David, N. 1980. A versatile basic program for fitting weight and seasonally oscillating length growth data. Pelagic, Demersal and Shellfish Cttes, $23 \mathrm{p}$.

Green, J., 1957. The growth of Scrobicularia plana (da Costa) in the Gwendraeth estuary. Journal of Marine Biology Assessment UK 36, 41-47.

Guelorget, O., Mazoyer-Mayére, C., 1983. Croissance, biomasse et production de Scrobicularia plana dans une lagune méditerranéenne: l'étang du Prévost à Palavas (Hérault, France). Vie Marine 5, 12-22.

Guerreiro, J., 1998. Growth and production of the bivalve Scrobicularia plana in two southern European estuaries. Vie et Milieu - Life and Environment 48, 121-131.

Hughes, R.N., 1969. A study of feeding in Scrobicularia plana. Journal of Marine Biology Assessment UK 49, 805-823.
Hughes, R.N., 1970a. An energy budget for a tidal flat population of the bivalve Scrobicularia plana (da Costa). Journal of Animal Ecology 39, 357-381.

Hughes, R.N., 1970b. Population dynamics of the bivalve Scrobicularia plana (da Costa) on an intertidal mud flat in North Wales. Journal of Animal Ecology 39, 333-356.

Lillebø, A.I., Pardal, M.A., Marques, J.C., 1999. Population structure, dynamics and production of Hydrobia ulvae (Pennant) (Mollusca: Prosobranchia) along an eutrophication gradient in the Mondego estuary (Portugal). Acta Oecológica 20, 289-304.

de Jonge, V.N., Jong, D.J., Katwijk, M.M., 2000. Policy plans and management measures to restore eelgrass (Zostera marina L.) in the Dutch Wadden Sea. Helgoland Marine Research 54, 151-158.

Kennish, M.J., 2000. Anthropogenic impacts and the National Estuary Program. In: Kennish, M.J. (Ed.), Estuary Restoration and Maintenance. The National Estuary Program. CRC Press, Washington DC, $359 \mathrm{pp}$.

Marques, J.C., Pardal, M.A., Nielsen, S.N., Jørgensen, S.E., 1997. Analysis of the properties of exergy and biodiversity along an estuarine gradient of eutrophication. Ecological Modelling 102, $155-157$.

Marques, J.C., Nielsen, S.N., Pardal, M.A., Jørgensen, S.E., 2003. Impact of eutrophication and river management within a framework of ecosystem theories. Ecological Modelling 166, 147-168.

Martins, I., Pardal, M.A., Lillebø, A.I., Flindt, M.R., Marques, J.C., 2001. Hydrodynamics as a major factor controlling the occurrence of green macroalgal blooms in a eutrophic estuary. A case study on the influence of precipitation and river management. Estuarine, Coastal and Shelf Science 52, 165-177.

Nogueira, A.J.A. (1992) ANAMOD - extracção dos componentes modais de distribuições de frequências de variáveis biométricas. Trabalho de síntese apresentado para prestação de provas de aptidão pedagógica e capacidade científica. University of Coimbra, 67 p.

Norkko, A., Cummings, V.J., Thrush, S.F., Hewitt, J.E., Hume, T., 2001. Local dispersal of juvenile bivalves: implications for sandflat ecology. Marine Ecology Progress Series 212, 131-144.

Pardal, M.A., Marques, J.C., Metelo, I., Lillebø, A.I., Flindt, M.R., 2000. Impact of eutrophication on the life cycle, population dynamics and production of Amphitoe valida (Amphipoda) along an estuarine apatial gradient (Mondego estuary, Portugal). Marine Ecology Progress Series 196, 207-219.

Pardal, M.A., Cardoso, P.G., Sousa, J.P., Marques, J.C., Raffaelli, D., 2004. Assessing environmental quality: a novel approach. Marine Ecology Progress Series 267, 1-8.

Raffaeli, D.G., Raven, J.A., Poole, L.J., 1998. Ecological impact of green macroalgal blooms. Oceanography Marine Biology 36, 97-125.

Sola, J.C., 1997. Reproduction, population dynamics growth and production of Scrobicularia plana da Costa (Pelecypoda) in the Bidasoa estuary, Spain. Netherlands Journal of Aquatic Ecology 30 (4), 283-296. 